\title{
Thermal-Hydraulic Performance Analysis of Twin-Pipes for Various Future District Heating Schemes
}

\author{
Milad Khosravi ${ }^{1}$ and Ahmad Arabkoohsar ${ }^{2, *}$ \\ 1 Department of Civil Engineering, Razi University, Kermanshah, Iran; khosravi.mi@razi.ac.ir \\ 2 Department of Energy Technology, Aalborg University, 6700 Esbjerg, Denmark \\ * Correspondence: ahm@et.aau.dk
}

Received: 7 March 2019; Accepted: 1 April 2019; Published: 4 April 2019

\begin{abstract}
Future energy systems will come with a 100\% share of renewable energy and high integration of energy systems. District heating and cooling systems will be undeniable parts of the future energy systems, as they pave the bed for high-efficiency, low cost, and clean production. District heating systems may come into a wide range of designs in the future. Currently, most of the world's district heating systems are based on the third generation design while everything in this framework is on the verge of a transition to the fourth generation. A large number of technologies for the future district heating systems has been proposed so far, among which low-, ultralow- and variable-temperature systems seem more of qualification. This study employs computational fluid dynamics to make a comprehensive examination of the compatibility of regular twin-pipes with various potential district heating schemes for future energy systems. The results show that both lowand ultralow-temperature systems could efficiently use regular twin-pipes commonly used in the third generation district heating systems, though the insulation of the pipe could be proportionally strengthened based on a techno-economic trade-off. In contrast, the results show that the thermal inertia of the pipe does not allow the variable-temperature district heating system to effectively operate when the transmission pipeline is longer than a limited length. Therefore, a regular heat distribution network may not be an appropriate host for a variable-temperature district heating scheme unless decentralized heat production units come into service.
\end{abstract}

Keywords: low-temperature district heating; ultralow-temperature district heating; variable-temperature district heating; twin-pipe; thermal-hydraulic performance; thermal inertia

\section{Introduction}

District heating and cooling systems will be the key elements of future smart energy systems [1]. According to [2], in a smart energy system, there must be strong synergies between the district energy systems and other energy sectors. As such, district energy systems (including heating) show high potential for the utilization of renewable sources, where a further certain feature of the smart energy systems is the high integration of renewable energy [3].

Today, most of the world's district heating systems are based on an advanced design and characteristics so-called the third generation district heating systems [4]. Two of the main features of the third generation district heating systems are the material/components employed and their lower operating temperatures compared to the previous generations. Here, the supply temperature is below $100{ }^{\circ} \mathrm{C}$ and pressurized water is the heat carrier. The circulation is carried out by central pumps, and medium-temperature radiators or under-floor heating are the main space heating methods. Domestic hot water is supplied either directly by plate heat exchangers or by employing storage tanks and plate heat exchangers [5]. Apart from the revision of the employed technologies in the heat production chain in order to increase the efficiency, reliability, and sustainability (bringing CHP units, biomass and 
waste incineration plants, heat pumps, etc.), a revolution of the distribution/transmission components took place for this generation of district heating systems as well. Here, the main components are the prefabricated compact substations, the compact stainless steel plate heat exchangers, the valves, and more importantly the pre-insulated twin-pipes buried directly into the ground while in the first two generations, regular pipes with separate insulations for supply and return lines were used [6].

District heating technology is, however, on the verge of transition to its fourth generation where the temperature of supply is to be as low as possible, there is a concrete integration between the district heating system and the other energy sectors, the share of renewable energy is high, etc. [3]. Reducing the supply temperature not only reduces the rate of losses from the system (and subsequently increases the efficiency of supply and distribution) but also enables for further integration of low-temperature renewable energy and waste heat sources [7]. Generally, the lower the supply temperature, yet being sufficient to cover the demanded temperature, the more it is desirable, though it might have some challenges as well. Properly meeting the comfort standard requirements, the risk of legionella generation and technical/societal foundation preparation for this transition are of the main challenges in this regards [8]. Therefore, for the fourth generation of district heating, as a necessity, a major revision of the system components is also required to adequately address the transition challenges.

There is a large number of studies in the literature introducing and investigating new designs of district heating systems for future energy systems. Low-temperature (LT), ultralow-temperature (ULT), and variable-temperature (VT) district heating systems are some of the most interesting schemes investigated over the last years. Some of the most recent works in this framework are introduced hereunder.

Generally, the concept of LT district heating (LTDH) system offers to decrease the supply/return temperatures to about $50-55 / 30-35{ }^{\circ} \mathrm{C}$ [9]. Nord et al. [8] comprehensively discussed the challenges of employing LTDH systems in Norway. They concluded that the heat loss could be reduced by lowering the supply temperature from $80{ }^{\circ} \mathrm{C}$ to $55^{\circ} \mathrm{C}$, though competitiveness of LTDH might be decreased for the heat densities lower than $1 \mathrm{MWh} / \mathrm{m}$. Im and Liu [10] presented a feasibility study on the LTDH systems with bilateral heat trade model. They proved that their proposed solution can alleviate the inefficiency arising from mismatching of heat demand and supply in the consumer side significantly. Cai et al. [11] investigated the use of electric boilers in LTDH systems and showed that by such a measure, i.e., a lower supply temperature and intelligent components, can improve the heat distribution system efficiency and turn district heating into an integrated part of the future smart energy systems. Averfalk and Werner [12] proposed a highly novel LTDH scheme where along with the lower supply and return temperatures, the system consists of three principal changes: three-pipe distribution networks, apartment substations, and longer thermal lengths for heat exchangers. Li et al. [13] investigated the integration of LTDH systems with industrial parks for the utilization of low-grade waste heat available in such sites.

In a ULT district heating (ULTDH) system, the supply and return temperatures come even to lower ranges of about $40-45^{\circ} \mathrm{C}$ and $25^{\circ} \mathrm{C}$, respectively [14]. Yang and Svendsen [15] proposed the integration of a central heat pump and local boosters with a ULTDH system and investigated this proposal for a low-heat-density area in Denmark. The results showed that the proposed design of the ULTDH system has a better performance compared to the existing methods in terms of energy, exergy, and economy due to substantial savings from the distribution heat loss. Vivian et al. [16] evaluated the cost of heat for the end-users in ULTDH networks. It was concluded that the system is already competitive with individual gas boilers if a local low-temperature heat source can be recovered with minor marginal costs. Zuhlsdorf et al. [17] proposed using zeotropic mixtures for improving the performance of booster heat pumps in ULTDH systems. Although they found the mixed working fluids resulting in a higher investment cost, the economic performance was comparable to the pure fluids while the mixtures showed similar performance as the pure fluids at off-design conditions. Ommen et al. [18] analyzed the performance of ULTDH systems with utility plant and booster heat pumps, observing a performance improvement of $12 \%$ for the reference calculations when the system 
was supplied by central heat pumps. In another work, they designed a new heat pump furnished substation configuration for multifamily buildings in ULTDH systems, finding it energetically and economically interesting [19]. Knudsen et al. [20] developed a model predictive control for demand response of domestic hot water preparation in ULTDH systems.

In a VTDH system, however, the supply temperature is not stable and fluctuates between low and high values periodically during a day to keep the heat losses as low as possible [21]. A team of researchers in the Netherlands has continued to work on this concept. In this project, the low supply temperature is $45^{\circ} \mathrm{C}$ and the high supply temperature is $70^{\circ} \mathrm{C}$. The system employs individual heat storage tanks for supplying domestic hot water of the end-users when working on low-temperature supply mode [22]. Moallemi et al. [23] presented their own version of this concept using decentralized neighborhood-scale heat storage units for a case study in Brazil and found their simulation results interesting if not considering the effects of the dynamic operation and the thermal inertia of the pipes. In another work, Arabkoohsar [24] investigated the use of decentralized heat pumps in a VTDH system to keep the transmission pipeline always at an ultralow-temperature level and bring the temperature variation in neighborhood-scale pipes.

In this study, the compatibility of twin-pipes, which are commonly used in the existing district heating systems, with the three discussed potential future district heating schemes is thoroughly investigated. Indeed, the objective is to see if the proposed future district heating systems are realistically feasible with the existing twin-pipes or there should be a revision of the pipes to make them practically implementable. For this, the thermal-hydraulic performance of such pipes is investigated via computational fluid dynamic methods (finite volume approach) in ANSYS FLUENT software.

\section{Twin-Pipes in District Heating Systems}

Twin-pipes came into service when district heating technology jumped into its third generation design from the second generation concept. This concept change comprised the extremely lower temperatures of supply and return and a fundamental revision in the components of the system, including the pipeline structure [25]. Figure 1 shows the schematic of a piece of a twin-pipe with its various components marked on it. As the figure shows, in a twin-pipe, both of the supply and return lines come into a single outer casing while efficient insulation (usually polyurethane foam-PUR) prevents them exchanging heat to each other and the ambient.

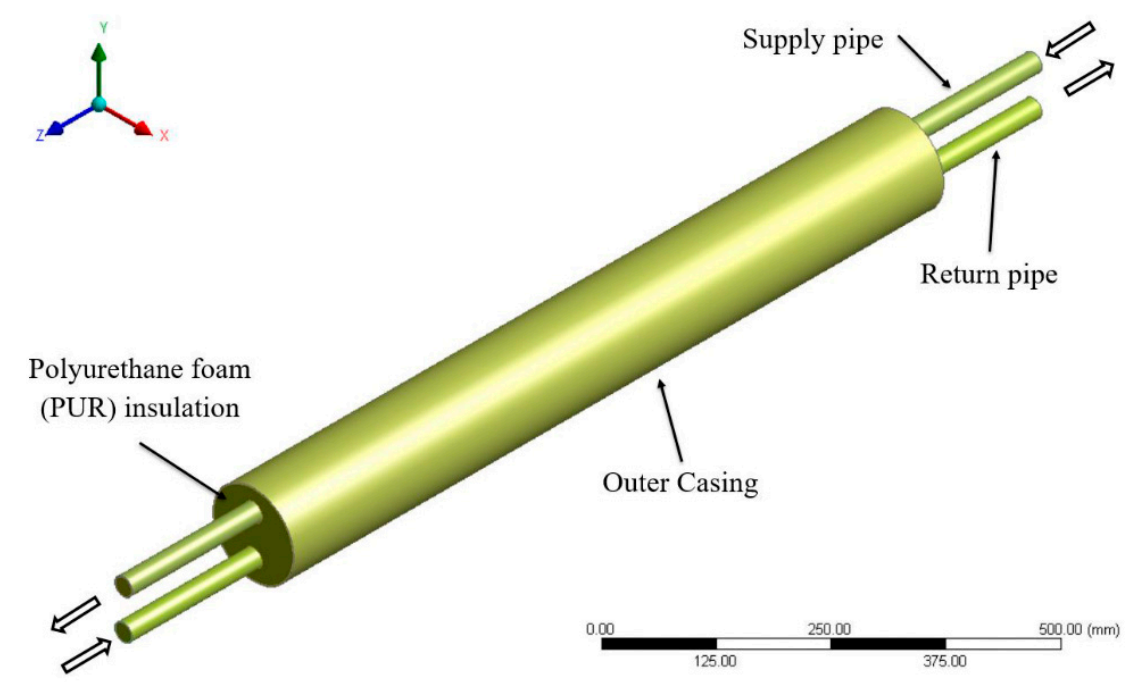

Figure 1. Schematic of a piece of a twin-pipe.

In this work, a typical twin-pipe is considered to fulfill the investigations. Table 1 presents information about the dimensions of different typical twin-pipes usually seen in various sections of a district heating pipeline including the transmission part, the street branch pipes, and the house 
connection pipes. As the focus of this study is on the transmission section of the pipeline, pipe type 5 is the one investigated in this work.

Table 1. Dimensions of various twin-pipes [26].

\begin{tabular}{cccccc}
\hline \multirow{2}{*}{ Pipe Type } & \multicolumn{2}{c}{ Pipe } & \multicolumn{2}{c}{ Casing } \\
\cline { 2 - 6 } & $\begin{array}{c}\text { Nominal } \\
\text { Diameter }(\mathbf{m m})\end{array}$ & $\begin{array}{c}\text { Outer Diameter } \\
\mathbf{( m m )}\end{array}$ & $\begin{array}{c}\text { Thickness } \\
\mathbf{( m m})\end{array}$ & $\begin{array}{c}\text { Outer Diameter } \\
(\mathbf{m m})\end{array}$ & $\begin{array}{c}\text { Thickness } \\
(\mathbf{m m})\end{array}$ \\
\hline Type 1 & 20 & 26.9 & 2.6 & 125 & 3 \\
Type 2 & 20 & 26.9 & 2.6 & 140 & 3 \\
Type 3 & 65 & 76.1 & 2.9 & 225 & 3.5 \\
Type 4 & 65 & 76.1 & 2.9 & 250 & 3.5 \\
Type 5 & $\mathbf{2 0 0}$ & $\mathbf{2 1 9 . 1}$ & $\mathbf{4 . 5}$ & $\mathbf{5 6 0}$ & $\mathbf{6}$ \\
Type 6 & 200 & 219.1 & 4.5 & 630 & 6.6 \\
\hline
\end{tabular}

Table 2. Further information about the characteristics of the pipes and district heating medium (i.e., water).

Table 2. Characteristics of twin-pipes and district heating flow through the pipes [26].

\begin{tabular}{|c|c|c|c|c|c|}
\hline Component & Material & $\begin{array}{l}\text { Density } \\
\left(\mathrm{kg} / \mathrm{m}^{3}\right)\end{array}$ & $\begin{array}{l}\text { Specific Heat } \\
(\mathrm{J} / \mathrm{kg} \cdot \mathrm{K})\end{array}$ & $\begin{array}{l}\text { Thermal Conductivity } \\
(\mathrm{W} / \mathrm{m} \cdot \mathrm{K})\end{array}$ & $\begin{array}{l}\text { Viscosity } \\
(\mathrm{kg} / \mathrm{m} \cdot \mathrm{s})\end{array}$ \\
\hline Heat Carrier & Water & 982 & 4136.5 & 0.65 & 0.001 \\
\hline Insulation & PUR & 30 & 133 & 0.021 & - \\
\hline Pipe & Steel & 8030 & 502.5 & 16.27 & - \\
\hline
\end{tabular}

Note that the thermal conductivity and density of water may change as the temperature varies, however, this change is so small that it is considered negligible in this study.

Table 3 presents information about the three different district heating systems under evaluation in this work.

Table 3. Characteristics of the three district heating schemes.

\begin{tabular}{cccc}
\hline District Heating Type & Supply Temperature $\left({ }^{\circ} \mathbf{C}\right)$ & Return Temperature $\left({ }^{\circ} \mathbf{C}\right)$ & Pressure $(\mathbf{M P a})$ \\
\hline ULTDH & 45 (all the time $)$ & 25 (all the time $)$ & 1.2 \\
LTDH & 55 (all the time $)$ & 30 (all the time $)$ & 1.2 \\
VTDH & $70(2 \mathrm{~h}$ a day $) / 45(22 \mathrm{~h}$ a day $)$ & $35(2 \mathrm{~h}$ a day $) / 25(22 \mathrm{~h}$ a day $)$ & 1.2 \\
\hline
\end{tabular}

\section{Governing Equations and the Solution Method}

In this section, the governing equations on the thermal and hydraulic behavior of twin-pipes and the heat carrier (the solid and the fluid sides) are presented. Then, the numerical solution method is explained in details.

\subsection{Governing Equations}

The governing equations on the motion of an incompressible flow are Reynold-Averaged Navier-Stokes, which can be written in the following format in a Cartesian coordinate [27]:

$$
\begin{gathered}
\frac{\partial \rho u_{i}}{\partial x_{i}}=0 \\
\frac{\partial u_{i}}{\partial t}+\frac{\partial u_{i} u_{j}}{\partial x_{j}}=-\frac{1}{\rho} \frac{\partial p}{\partial x_{i}}+\frac{\partial}{\partial x_{j}}\left[v\left(\frac{\partial u_{i}}{\partial x_{j}}+\frac{\partial u_{j}}{\partial x_{i}}-\frac{2}{3} \delta_{i j} \frac{\partial u_{l}}{\partial x_{l}}\right)\right]+\frac{\partial}{\partial x_{j}}\left(-\overline{u_{i}^{\prime} u_{j}^{\prime}}\right),
\end{gathered}
$$


In which, $u_{i}, u_{j}$, and $u_{l}$ are the velocity components in the directions of $i, j$, and $l$, respectively. $x_{i}$, $x_{j}$, and $x_{l}$ are the Cartesian coordinates, $\delta_{i j}$ is the Kronecker delta function, $v$ and $\mu$ are the kinematic and dynamic viscosities, and $\rho$ is density.

The Reynolds stresses term $\left(-\overline{u_{i}^{\prime} u_{j}^{\prime}}\right)$ is evaluated using Boussinesq assumption as follow:

$$
-\overline{u_{i}^{\prime} u_{j}^{\prime}}=v_{t}\left(\frac{\partial \bar{u}_{i}}{\partial x_{j}}+\frac{\partial \bar{u}_{j}}{\partial x_{i}}\right)-\frac{2}{3} k \delta_{i j},
$$

where, $v_{t}$ is turbulent viscosity. For considering the effect of turbulence the Realizable $k-\varepsilon$ model is used in this work. This model is based on the solution of the two heat transfer equations of turbulent kinetic energy $(k)$ and dissipation of turbulence energy $(\varepsilon)$ as below [28]:

$$
\begin{gathered}
\frac{\partial k}{\partial t}+\frac{\partial k u_{j}}{\partial x_{j}}=\frac{\partial}{\partial x_{j}}\left[\left(v+\frac{v_{t}}{\sigma_{k}}\right) \frac{\partial k}{\partial x_{j}}\right]+G_{k}+G_{b}-\varepsilon, \\
\frac{\partial \varepsilon}{\partial t}+\frac{\partial \varepsilon u_{j}}{\partial x_{j}}=\frac{\partial}{\partial x_{j}}\left[\left(v+\frac{v_{t}}{\sigma_{\varepsilon}}\right) \frac{\partial \varepsilon}{\partial x_{j}}\right]+C_{1} S \varepsilon+C_{2} \frac{\varepsilon^{2}}{k+\sqrt{v \varepsilon}},
\end{gathered}
$$

where:

$$
C_{1}=\max \left[0.43, \frac{\eta}{\eta+5}\right], \eta=S \frac{k}{\varepsilon}, S=\sqrt{2 S_{i j} S_{i j}} .
$$

In these equations, $C_{2}$ is a constant, $\sigma_{k}$ and $\sigma_{\varepsilon}$ are turbulent Prandtl numbers for $k$ and $\varepsilon$. Also, $G_{k}$ and $G_{b}$ are the productions of turbulence kinetic energy due to the average velocity gradients and buoyancy, which can be given by the following equations, respectively.

$$
\begin{gathered}
G_{k}=-\overline{u_{i}^{\prime} u_{j}^{\prime}} \frac{\partial u_{j}}{\partial x_{i}}=v_{t} S^{2} \\
G_{b}=\beta g_{i} \frac{v_{t}}{P r_{t}} \frac{\partial T}{\partial x_{i}}
\end{gathered}
$$

where, $\beta$ and $g_{i}$ are the coefficient of thermal expansion and the gravity acceleration component in each direction. $P r_{t}$ is the turbulence Prandtl number for energy, considered as 0.85 here. As such, $S$ is the modulus of the mean rate-of-strain tensor, defined as:

$$
\begin{gathered}
S \equiv \sqrt{2 S_{i j} S_{i j}}, \\
S_{i j}=\frac{1}{2}\left(\frac{\partial u_{j}}{\partial x_{i}}+\frac{\partial u_{i}}{\partial x_{j}}\right),
\end{gathered}
$$

When the terms $k$ and $\varepsilon$ and calculated, the turbulent viscosity may be calculated by the following relations:

$$
\begin{gathered}
v_{t}=C_{\mu} \frac{k^{2}}{\varepsilon}, \\
C_{\mu}=\frac{1}{A_{0}+A_{s} \frac{k U^{*}}{\varepsilon}}, \\
U^{*} \equiv \sqrt{S_{i j} S_{i j}+\widetilde{\Omega_{i j}} \widetilde{\Omega_{i j}},} \\
\widetilde{\Omega_{i j}}=\Omega_{i j}-2 \varepsilon_{i j k} \omega_{k}, \\
\Omega_{i j}=\overline{\Omega_{i j}}-\varepsilon_{i j k} \omega_{k},
\end{gathered}
$$


where, $\overline{\Omega_{i j}}$ is the mean rate of rotation observed in the moving reference frame with the angular velocity of $\omega_{k}$. The rest of the parameters in the above formulation are given as follow:

$$
\begin{gathered}
A_{0}=4.04, A_{s}=\sqrt{6} \cos \phi, \\
\phi=\frac{1}{3} \cos ^{-1}(\sqrt{6} W), W=\frac{S_{i j} S_{j k} S_{k i}}{\widetilde{S}^{3}}, \widetilde{S}=\sqrt{S_{i j} S_{i j}}, S_{i j}=\frac{1}{2}\left(\frac{\partial u_{j}}{\partial x_{i}}+\frac{\partial u_{i}}{\partial x_{j}}\right), \\
C_{1 \varepsilon}=1.44, C_{2}=1.9, \sigma_{k}=1.0, \sigma_{\varepsilon}=1.2,
\end{gathered}
$$

The energy equation is used for calculating the rate of heat transfer as:

$$
\frac{\partial \rho E}{\partial t}+\frac{\partial}{\partial x_{i}}\left[u_{i}(\rho E+p)\right]=\frac{\partial}{\partial x_{j}}\left(k_{e f f} \frac{\partial T}{\partial x_{j}}\right),
$$

In which, $E$ is the total energy, $p$ is pressure, $T$ is temperature and $k_{e f f}$ is the effective thermal conductivity term given by:

$$
k_{e f f}=k+\frac{c_{p} \mu_{t}}{P r_{t}}
$$

where, $c_{p}$ is the specific thermal capacity.

Then, the energy flow for the solid side of the problem (the pipe body) can be written as:

$$
\frac{\partial}{\partial t}(\rho h)+\nabla \cdot(\vec{v} \rho h)=\nabla \cdot(k \nabla T)+S_{h}
$$

where, $h$ is sensible enthalpy and the second term on the left-hand side represents convective energy transfer due to rotational or translational motion of the solids. The terms on the right-hand side are the heat flux due to conduction and volumetric heat sources within the solid $\left(S_{h}\right)$, respectively.

The value of heat transfer between the wall surface and the fluid for a unit area of the wall is calculated as:

$$
q=h\left(T_{f}-T_{w}\right)
$$

in which, $h$ is the local convective heat transfer coefficient, $T_{f}$ is the local fluid temperature and $T_{w}$ is the local wall temperature. The heat transfer rate for the boundary of a solid cell of the pipe is calculated as below:

$$
q=\frac{k_{s}}{\Delta n}\left(T_{w}-T_{s}\right),
$$

where, $k_{S}$ is the thermal conductivity of the solid cell, $T_{S}$ is the local temperature of the solid cell, and $\Delta n$ is the distance of the center of the solid cell and the wall surface.

\subsection{Solution Method, Boundary Conditions, and Validation}

For the simulation of the heat transfer process in this work, first, the computational space is discretized by octagonal 3-D elements in a non-uniform grid. According to the importance of the heat distribution along the radius of the pipe, the meshing has been done with very small elements. Figure 2 shows the mesh grid made on a cross section of the pipe.

The boundary condition of uniform flow for the inlets and the boundary condition of static pressure for the outlets are used. The no-slip boundary condition for the walls is also considered here. Note that for the simulation of the flow behavior close to the wall, the standard wall function is used which is broadly used for industrial flows.

Due to the large geometry of the problem and the high cost of the computations, in this work, the momentum equations (Equation (2)) are considered in the governing equations only for analyzes where the effects of turbulence are important (e.g., for calculating the average Nusselt number and pressure drop). For the rest of the computations, energy and continuity equations assuming constant 
and uniform velocity are used only. This assumption eliminates the need for the momentum equation and makes the effects of the turbulent fluctuations and secondary flows negligible.

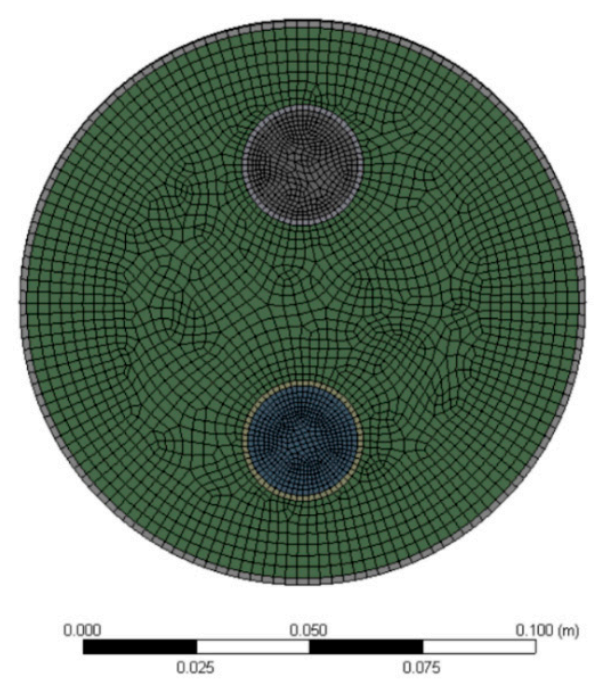

Figure 2. The mesh grid on the pipe cross-section.

The simulations are accomplished based on the finite volume method within the computational fluid dynamic model of ANSYS FLUENT.

Validation and grid sensitivity analysis:

Normally, in order to use a numerical model, one needs to first make sure about the validity of the developed model and accomplish a mesh grid sensitivity analysis. Table 4 gives information about the three different mesh grids considered in the simulations.

Table 4. Dimensions of mesh cells in different mesh grids.

\begin{tabular}{ccc}
\hline \multirow{2}{*}{ Grid Type } & \multicolumn{2}{c}{ Average Mesh Size (mm) } \\
\cline { 2 - 3 } & Radial Direction & Longitudinal Direction \\
\hline Grid A & 0.02 & 0.08 \\
Grid B & 0.01 & 0.04 \\
Grid C & 0.005 & 0.02 \\
\hline
\end{tabular}

Figure 3 compares the values obtained from the simulations with various mesh grid structures (A, B, and C) for the rate of heat transfer from the twin pipes (with different nominal diameters) and those reported by the pipe manufacturer. Therefore, not only does this figure present the results of the sensitivity analysis on the mesh grids, but it also is a reference for the validity of the results of the simulations. As seen, there is a very good agreement between the results obtained from the simulations (in all the mesh grid styles) and those reported by Logstor [26]. In this figure, the graph 'CFD results: Grid C + Simplified Model', which lies almost on the graph 'CFD results: Grid C' refers to the case in which the momentum equation is not included in the simulations for the sake of simplification. As seen, this simplification does not affect the accuracy of the simulations either.

Note that for all of the pipes with different diameters, their corresponding characteristics are considered just similar to the reference cases. The supply and return temperatures are $120{ }^{\circ} \mathrm{C}$ and $70{ }^{\circ} \mathrm{C}$, respectively.

As the pipeline length is to be quite long (10 km, here), for reducing the cost of computations, a griding towards the length direction is required to do the computations based on that. Figure 4 shows the effect of considering longer segments of the pipe in the calculations on the accuracy of the results. Here, the considered parameter is the overall heat loss rate from the pipe when used for a supply 
temperature of $70^{\circ} \mathrm{C}$ and the return temperature is $30^{\circ} \mathrm{C}$, the pipe is made of steel, the insulation is Series 1 , the nominal diameter of the pipe is $200 \mathrm{~mm}$ and the ambient temperature is $10^{\circ} \mathrm{C}$.

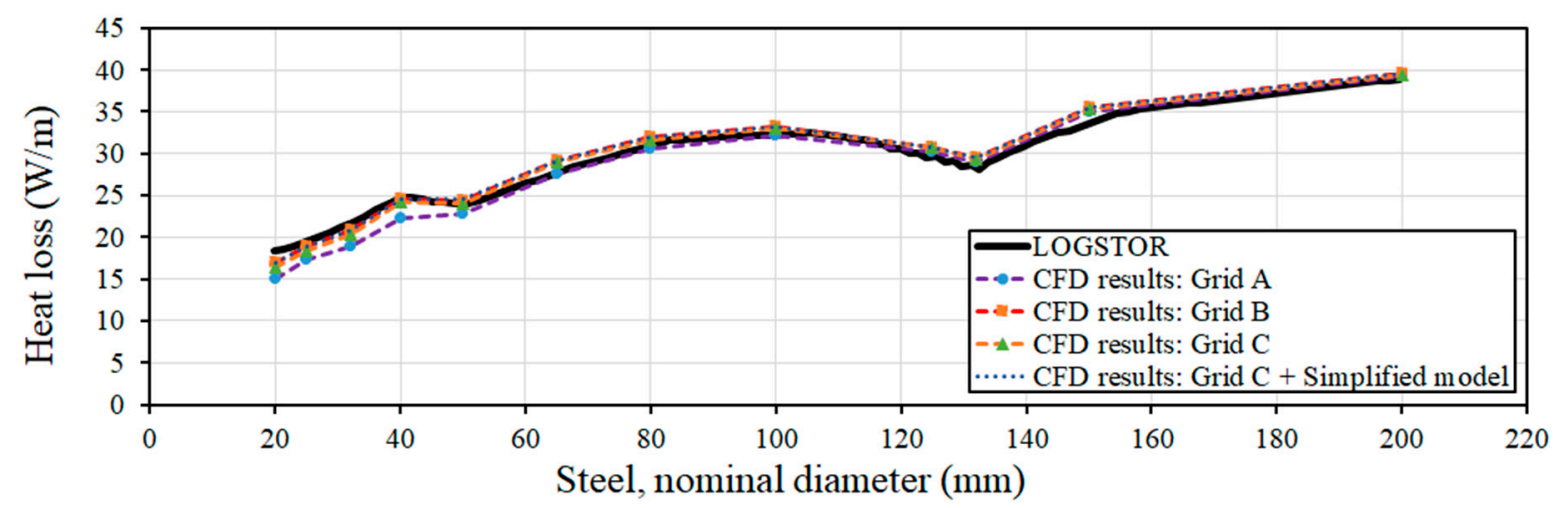

Figure 3. The mesh grid sensitivity analysis and validation of the CFD results.

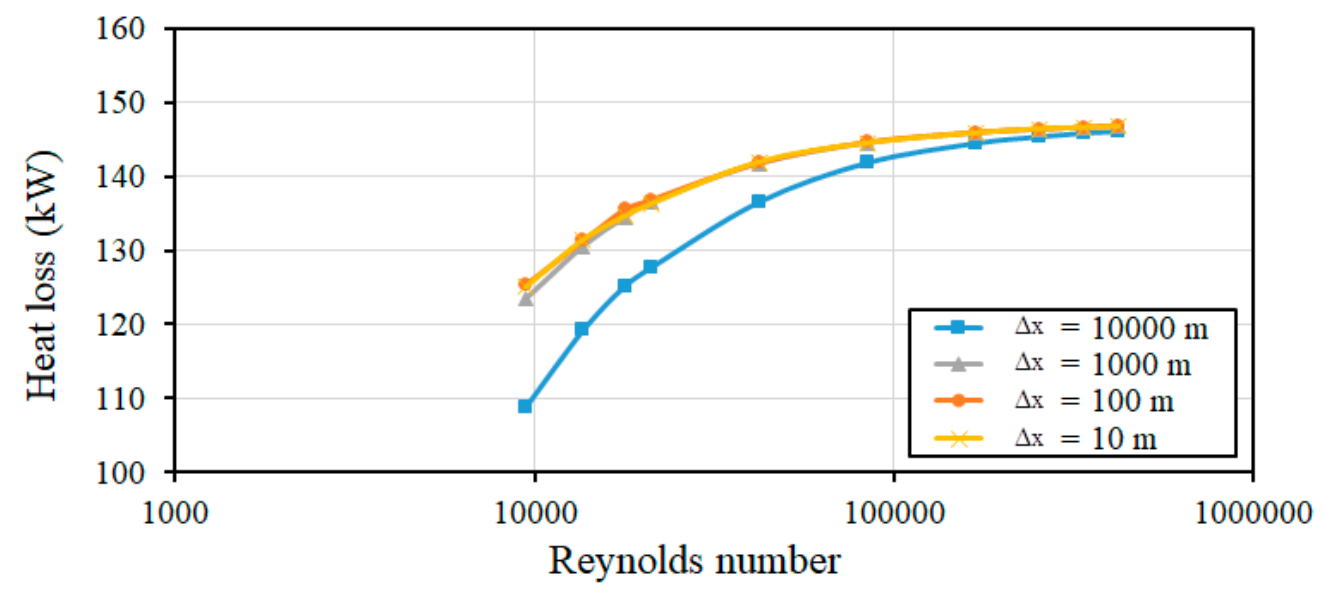

Figure 4. The effect of the grid size on length direction on the accuracy of the results.

According to the figure, as the segment length increases the accuracy of the calculations drops, however, segments up to $100 \mathrm{~m}$ do not affect the accuracy significantly. Here, at lower Reynolds numbers, where the deviation is larger, the error is just about $1 \%$ (from $125.1 \mathrm{~kW}$ to $123.5 \mathrm{~kW}$ ) and this error decreases when Reynolds number goes to higher values (though super high Reynolds values will not happen in district heating applications as the maximum velocity through the pipes is limited to $2 \mathrm{~m} / \mathrm{s}$ ). Thus, for reducing the computations cost, the segment length of $100 \mathrm{~m}$ is considered for meshing toward length direction of the pipe in the numerical simulations.

\section{Results and Discussion}

In this section, the results of the simulations carried out on the pipe in various scenarios are presented and discussed.

Figure 5 presents the contours of temperature distribution in the radial direction of the insulations in each of the three cases. The legends of the contours give an indication of the temperatures that the colors represent for each case.

Figure 6 presents the profile of temperature drop in the axial direction along the supply and return lines of the pipeline (up to $10 \mathrm{~km}$ ) for the three different scenarios. For making these graphs, the same ambient temperature $\left(5^{\circ} \mathrm{C}\right)$ is applied for all the three cases. As such, in order to make a fair comparison, the same heat delivery rate $(5 \mathrm{MW})$, instead of the same mass flow rate, is applied. Naturally, for delivering the same amount of heat to the end-users, the mass flow rate of different cases should be different (as a direct function of the temperature difference of the supply and return lines). 
Thus, the ULTDH system will result in the highest mass flow rate while the VTDH system when working on the high-temperature supply mode makes the lowest mass flow rate. It is reminded that the VTDH system has two operational modes. When it is on the low-temperature supply mode, it makes a profile just the same as the ULTDH case. As seen, the highest level of temperature drop is for the VTDH system while working on the high-temperature supply mode. It will be just about $1{ }^{\circ} \mathrm{C}$ and $0.23{ }^{\circ} \mathrm{C}$ for the supply and return lines, respectively. However, one should note that, based on the design of the VTDH system, this only applies for a short period of time a day, e.g., $2 \mathrm{~h}$, and the rest of the day, the temperature drop profile will be just similar to the ULTDH system. In this case, the temperature drop values for the supply and return lines over a $10 \mathrm{~km}$ pipeline will be $0.33^{\circ} \mathrm{C}$ and $0.07^{\circ} \mathrm{C}$, respectively. The LTDH system presents the temperature drop values of $0.52{ }^{\circ} \mathrm{C}$ and $0.14{ }^{\circ} \mathrm{C}$ as moderate temperature drop values among the three cases.

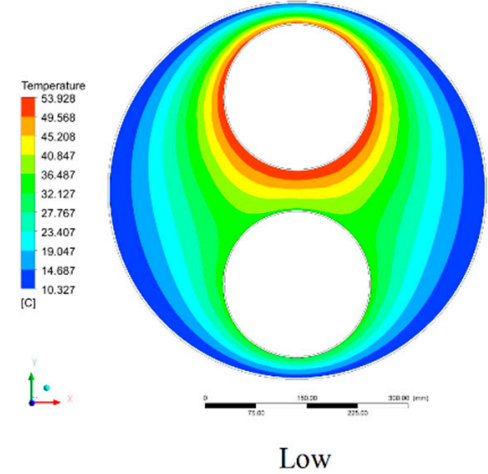

a

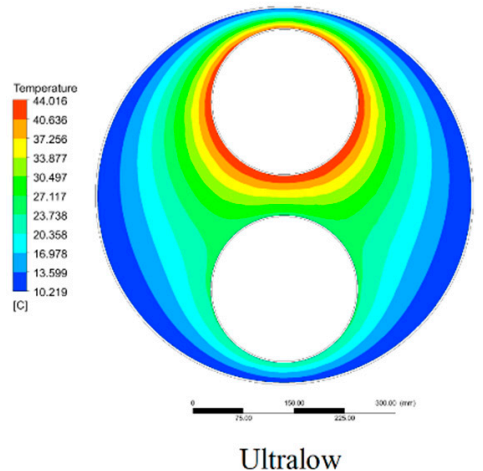

b

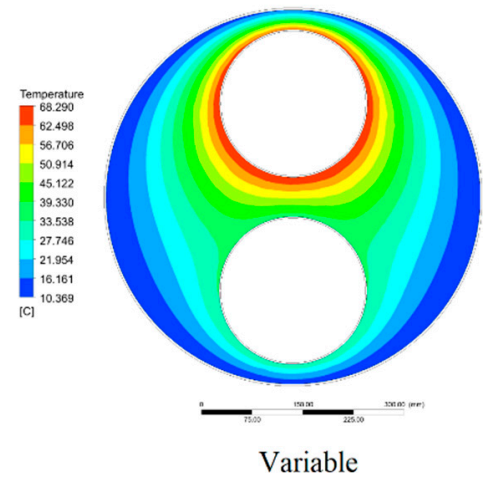

C

Figure 5. Contours of radial temperature distribution for the pipes through the insulations. (a) LowTemperature DH systems; (b) Ultralow-Temperature DH system; (c) Variable-Temperature DH system.
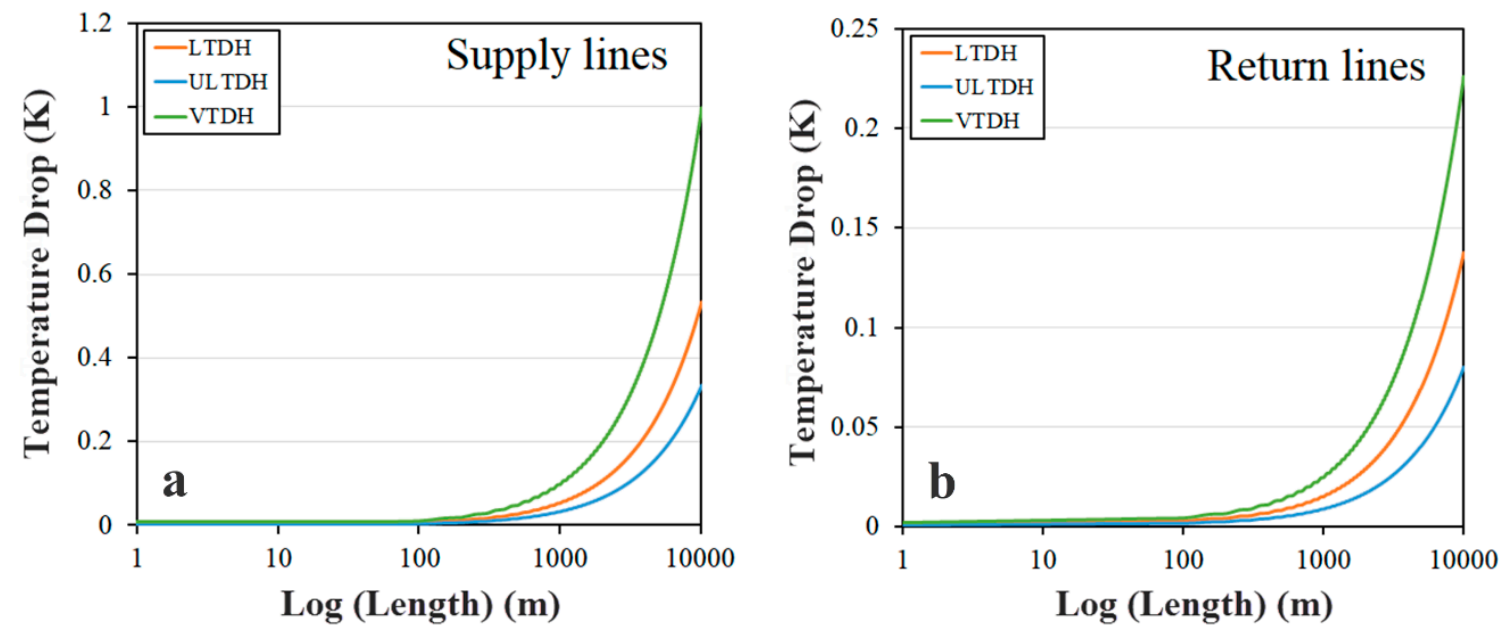

Figure 6. The temperature profile of the supply and return lines for different cases. (a) supply lines; (b) return lines.

Figure 7 investigates the rate of temperature drop along a $10 \mathrm{~km}$ pipeline for the three different cases if the same mass flow rate is applied through the pipe. Here again, the twin-pipe type 5 is considered for all the cases, the supply/return temperatures are $45 / 25^{\circ} \mathrm{C}, 55 / 30{ }^{\circ} \mathrm{C}$, and $70 / 35{ }^{\circ} \mathrm{C}$ for the ULTDH, LTDH, and VTDH systems, respectively, and the surrounding temperature is $5{ }^{\circ} \mathrm{C}$. Clearly, when the same mass flow rate is passing through a specific pipe, a higher temperature will make a larger heat loss, and subsequently, a larger temperature drop. Thus, expectedly, the VTDH system (in high-temperature supply mode) makes a higher temperature drop compared to the others. Naturally, when VTDH system goes to ultralow supply mode, the same trend as the ULTDH system 
will be observed. The LTDH system results in a moderate temperature drop among the three cases again. A similar trend is observed for the return lines as well. Comparing the values of losses in this figure and Figure 6, one could see that the level of temperature drop in this case is lower. This is mainly due to the fact that the maximum velocity of $2 \mathrm{~m} / \mathrm{s}$ has been considered for all the three cases, which gives a shorter time to the district heating water to exchange heat with the surrounding.
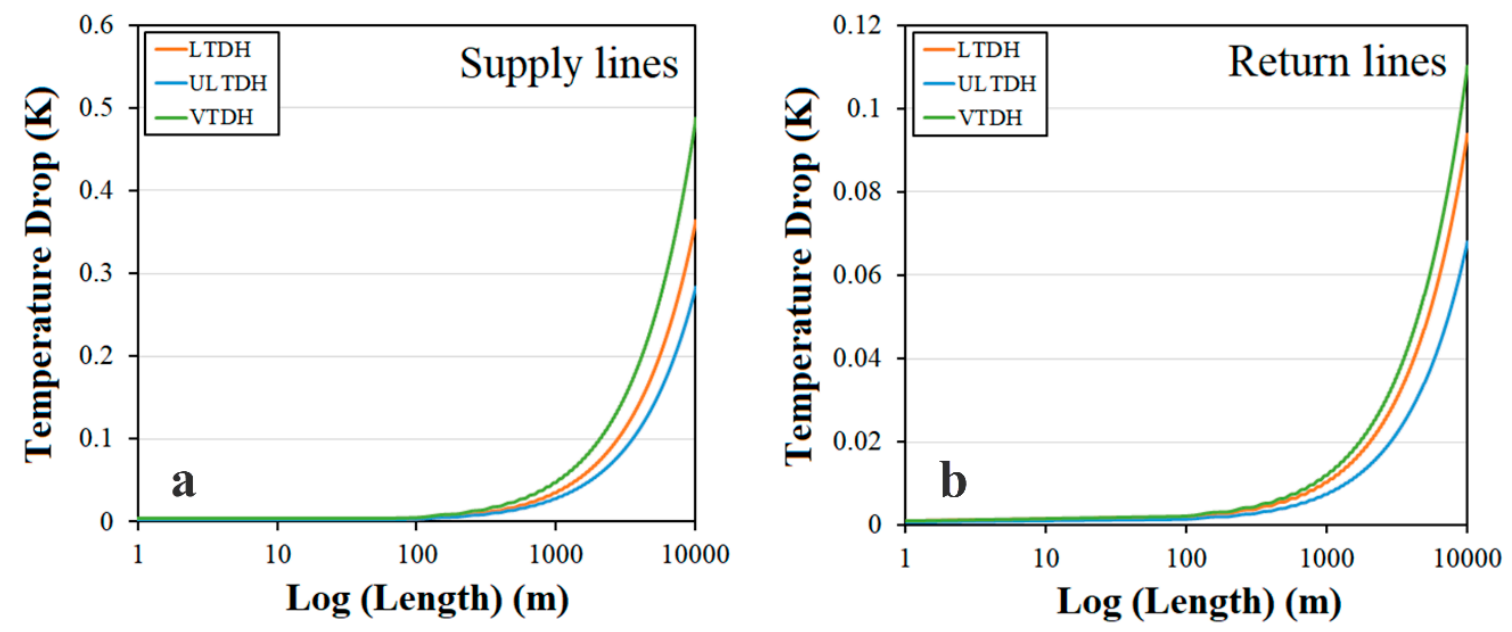

Figure 7. The rate of temperature fall along the pipeline for the three scenarios when the same mass flow rate is applied. (a) supply lines (b) return lines.

Figure 8 investigates the effect of Reynolds number on the level of total heat loss through the pipes in different cases. This includes the heat loss from the supply lines (the left panel), and the return lines (the right panel). As expected, regardless of the Reynolds number, for the same mass flow rate, the VTDH system while working in the high-temperature supply mode makes the higher rate of loss while the ULTDH system results in the lowest rate of heat loss. This is true for both the supply and return lines. On the other hand, the increase in the Reynolds number makes a growth in the rate of loss, though this effect is not that significant.
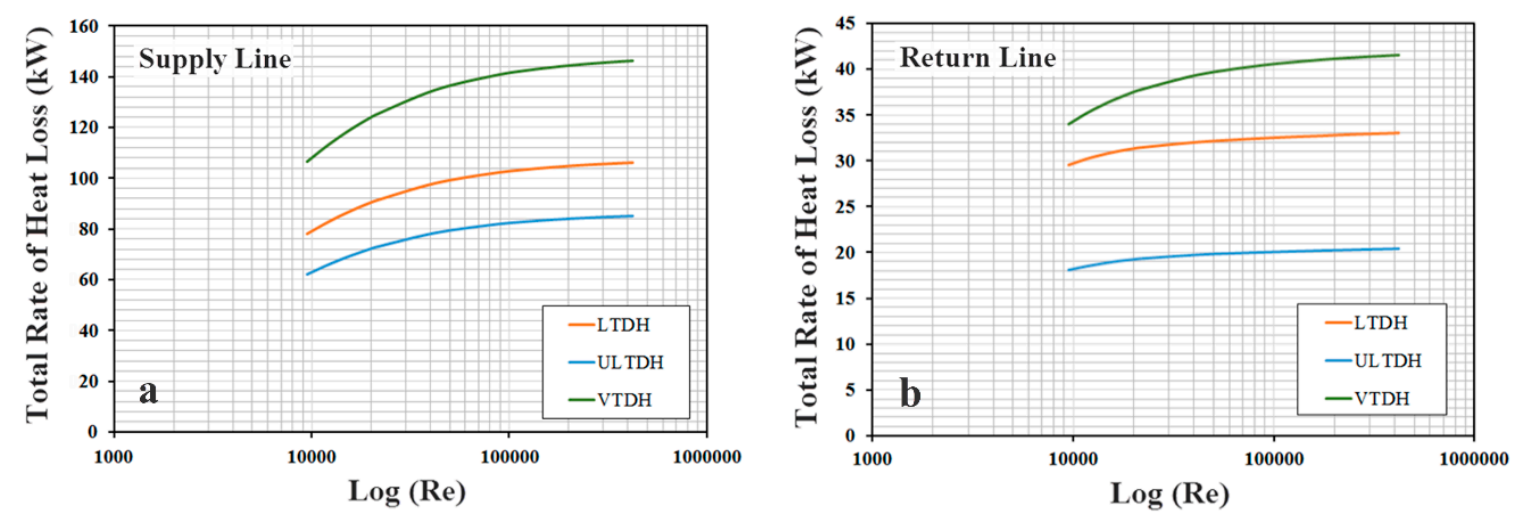

Figure 8. The effect of Reynolds number on the level of heat loss through the supply and return lines in each case. (a) supply lines; (b) return lines.

Figure 9 shows the total rate of heat loss from both of the supply and return lines along the $10 \mathrm{~km}$ pipelines. This figure, indeed, gives an indication of the summation of the losses reported in the above figure for each case. Naturally, the trends remain the same and the ULTDH system results in the lowest rate of loss while the LTDH system presents an average level of loss and the VTDH system (when in high-temperature supply mode) gives the highest rate of total heat loss. 


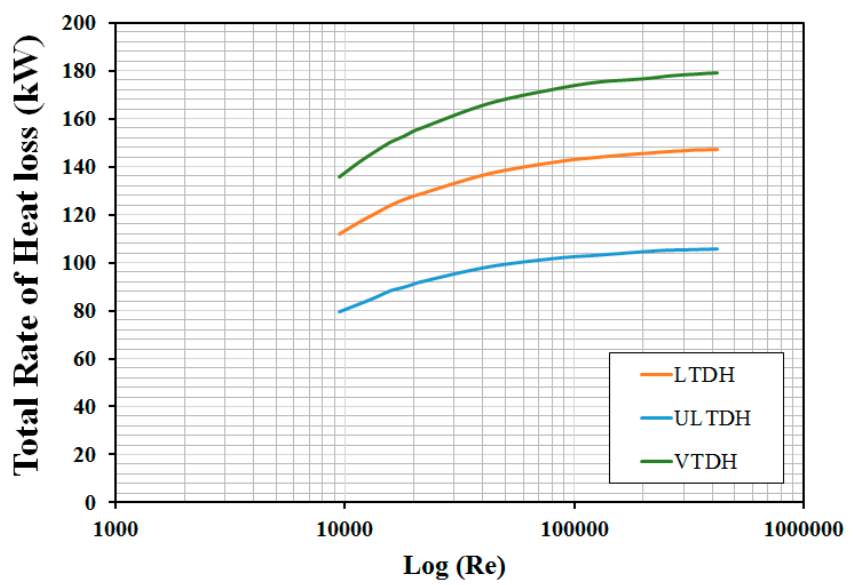

Figure 9. The effect of Reynolds number on the level of total rate of heat losses over the entire pipeline in each case.

Figure 10 illustrates the effect of Reynolds number on the level of temperature drop for the supply and return lines over the entire pipeline for each of the three scenarios. Again, the VTDH system while working at the high-temperature supply mode makes the largest value of temperature drop in the supply line while the ULTDH system makes the lowest value of temperature drop through that.
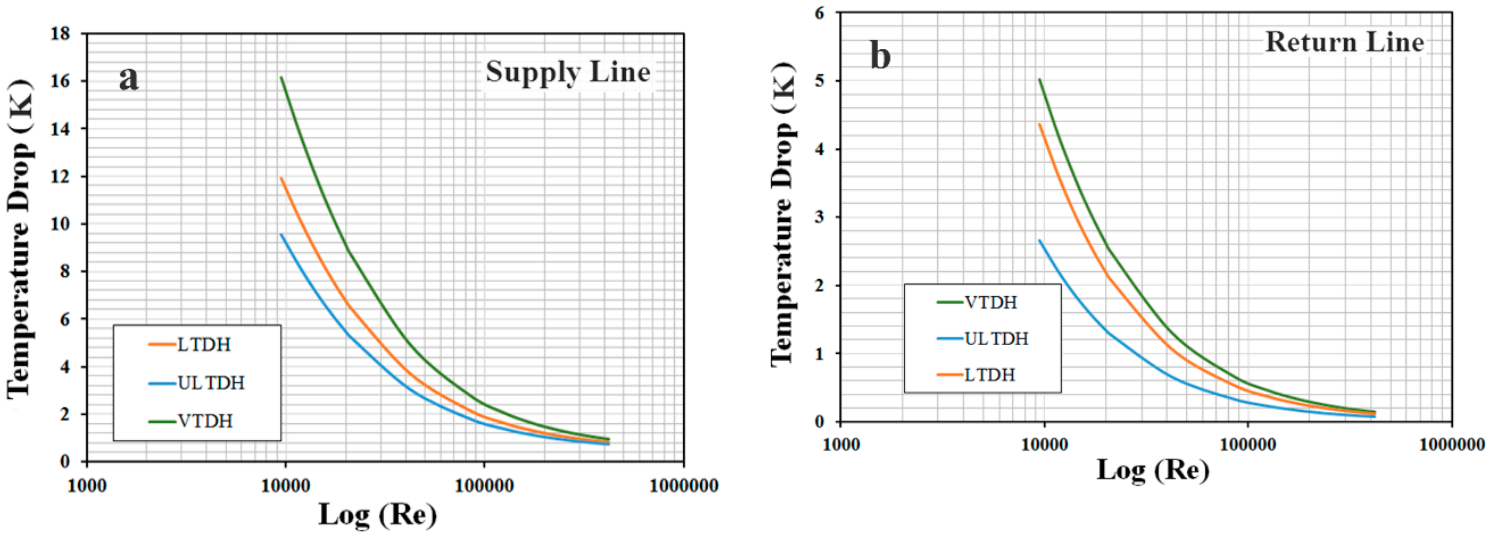

Figure 10. The effect of Reynolds number on the level of temperature drop over the entire pipeline in each case. (a) supply lines; (b) return lines.

Figure 11 illustrates the profile of pressure for a unit meter of the pipeline for the three cases. Here again, to make a fair comparison, the same amount of heat delivery (rather than a similar mass flow rate) is applied to the pipes in different cases. The presented pressure drop profiles are related to the supply lines only, as almost the same values as the supply lines are obtained for the return lines. Note that the value of pressure drop increases proportionally as the length of the pipe increases. The pressure drop values are important because they can represent the amount of work required for running the booster pumps along the paths for compensating the pressure losses through the pipes.

Figure 12 shows the variation of Nusselt number for each of the three cases as a function of Reynolds number. As seen, there is not a significant difference between different cases, neither in the supply lines nor through the return lines.

Figure 13 presents the profile of the heat loss from the supply and return lines of each case as a function of the angle. The right panel in the figure shows how the angle is considered, where the upper tube is the supply line and the lower tube is the return line. According to the figure, at angle $0^{\circ}$, where the supply line is closer to the surrounding soil, the loss is at its maximum level while it gets minimal when the angle is close to $180^{\circ}$. For the return line, the trend is revers because the supply line at angle $0^{\circ}$ heats it up, and the losses get maximal when the angel goes toward $180^{\circ}$. The noteworthy 
point is that the heat loss from the supply line to the return line is not considered as a loss for the whole pipe because it remains in the system.

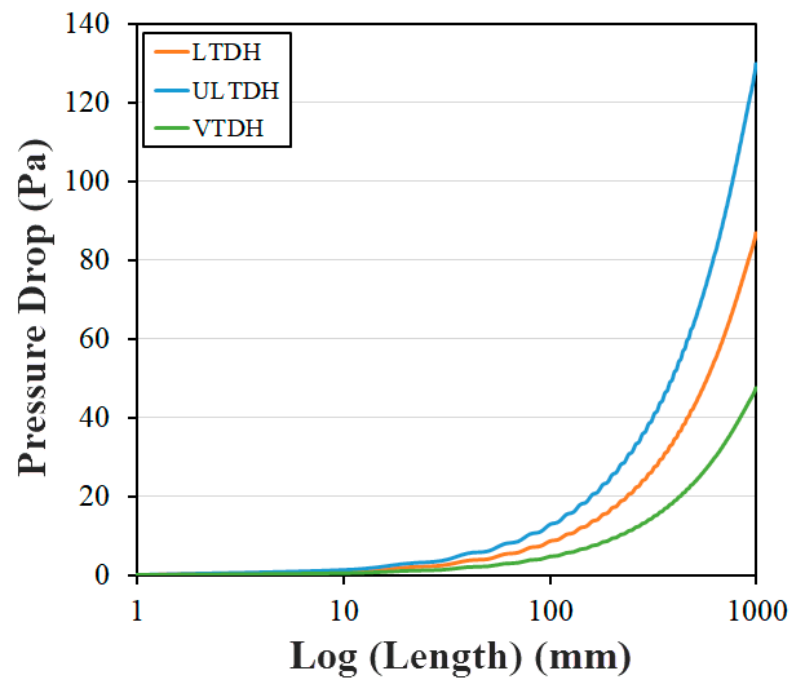

Figure 11. The level of pressure drop through the supply lines in each case.
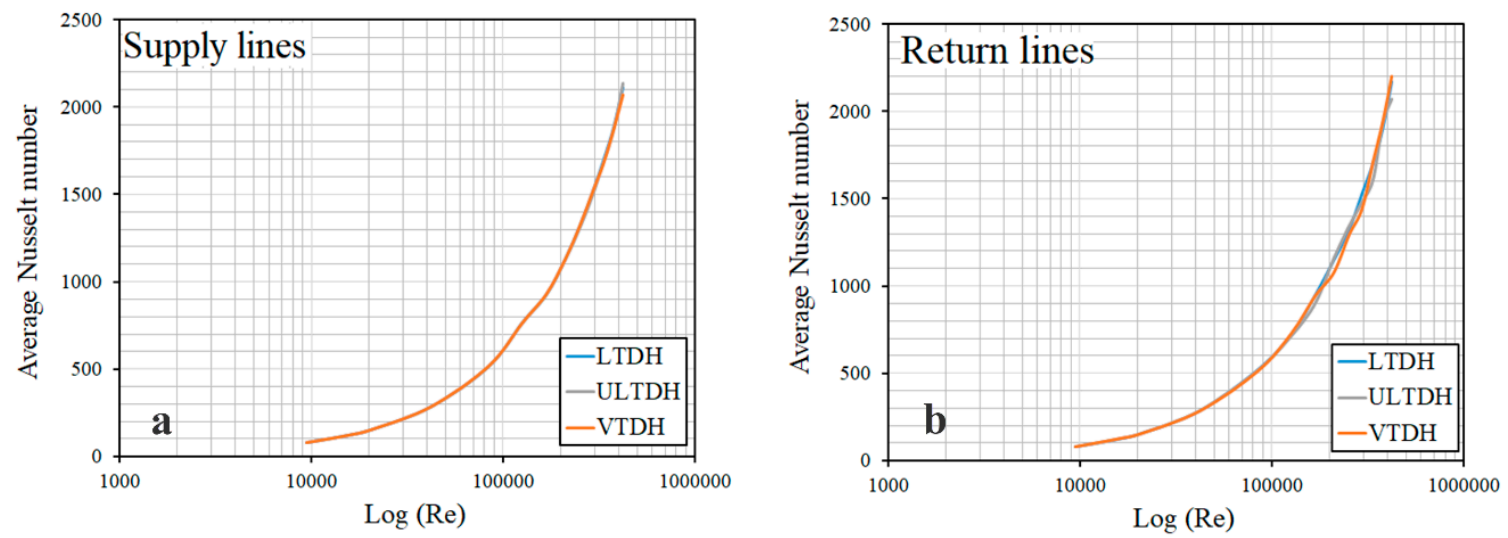

Figure 12. The effect of Reynolds number on the Nusselt number through the pipes in each case. (a) supply lines; (b) return lines.
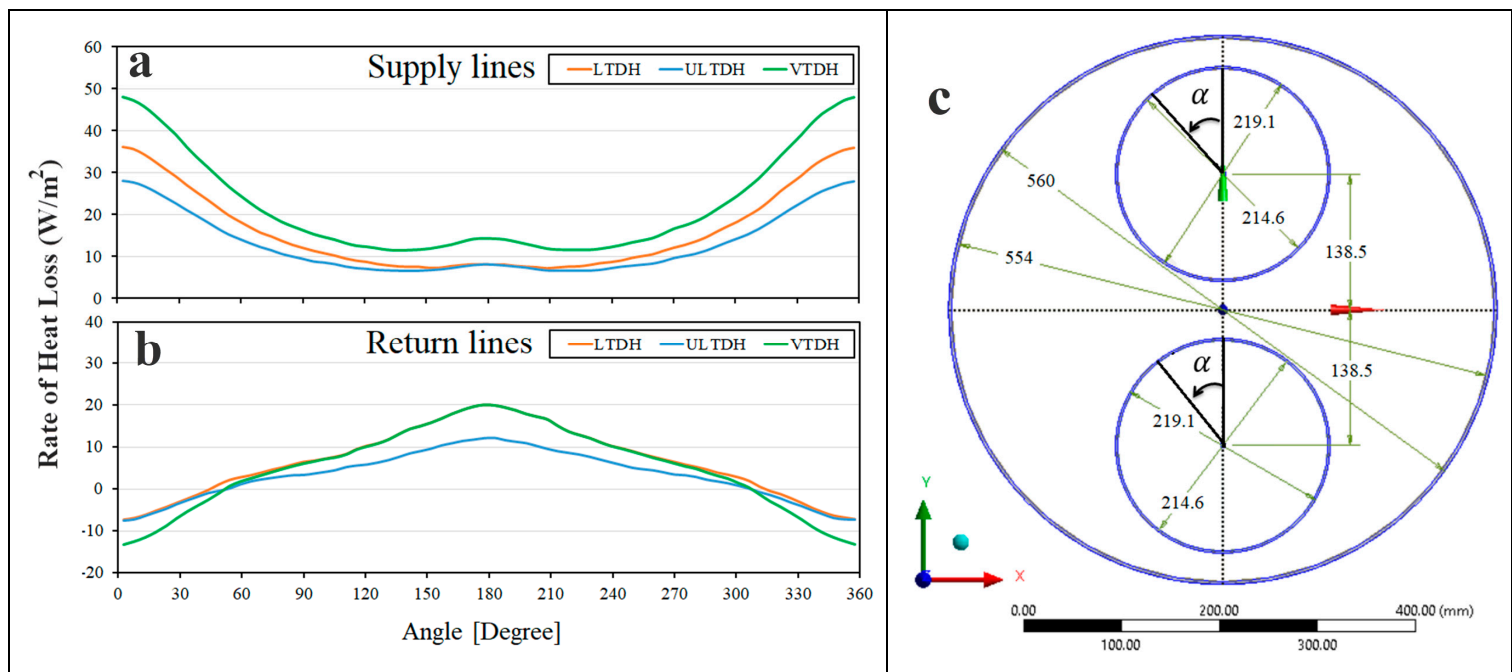

Figure 13. The rate of heat loss from the supply and return pipes as a function of angle in each case. (a) supply lines; (b) return lines; (c) pipe dimensions and angles. 
Figure 14 shows the effect of variation in the insulation thickness of each case on the rate of heat losses. The considered range for the thickness of the insulation come in the form of the outer diameter of the casing just above the outer diameter of the pipes up to an outer diameter of $870 \mathrm{~mm}$. According to the figure, although the effect of increasing the thickness of the insulation gets milder as the thickness grows, a significant reduction in the rate of loss is seen in the lower ranges of the outer diameter. For example, an increase of the outer diameter from $554 \mathrm{~mm}$ to $590 \mathrm{~mm}$ results in about $20 \%, 18 \%$, and $14 \%$ less heat loss from the supply lines of the VTDH system (from $150 \mathrm{~kW}$ to 123 $\mathrm{kW}$ ), the LTDH system (from $110 \mathrm{~kW}$ to $90 \mathrm{~kW}$ ) and ULTDH (from $85 \mathrm{~kW}$ to $72 \mathrm{~kW}$ ), respectively. The rates of improvement for the return lines are even more impressive, where for the VTDH, LTDH, and ULTDH systems the saving rates of respectively $33 \%, 32 \%$, and $30 \%$ are observed for the same amount of insulation strengthen. The heat loss values (before and after increasing the insulation thickness) for the whole pipe, including both supply and return lines, are $180 \mathrm{~kW}$ to $143 \mathrm{~kW}, 138 \mathrm{~kW}$ to $110 \mathrm{~kW}$, and $105 \mathrm{~kW}$ to $83 \mathrm{~kW}$, respectively. Since the main objective of lowering the operating temperatures in district heating systems is getting a lower rate of loss, the reinforcement of the insulations in the transmission pipelines compared to the existing standard pipes could be highly helpful. Of course, this needs an optimization based on techno-economic considerations to see how much it would cost to make such a reinforcement of the insulation per meter of the pipe and how much benefit it would make. This will, naturally, be different for various district heating schemes.
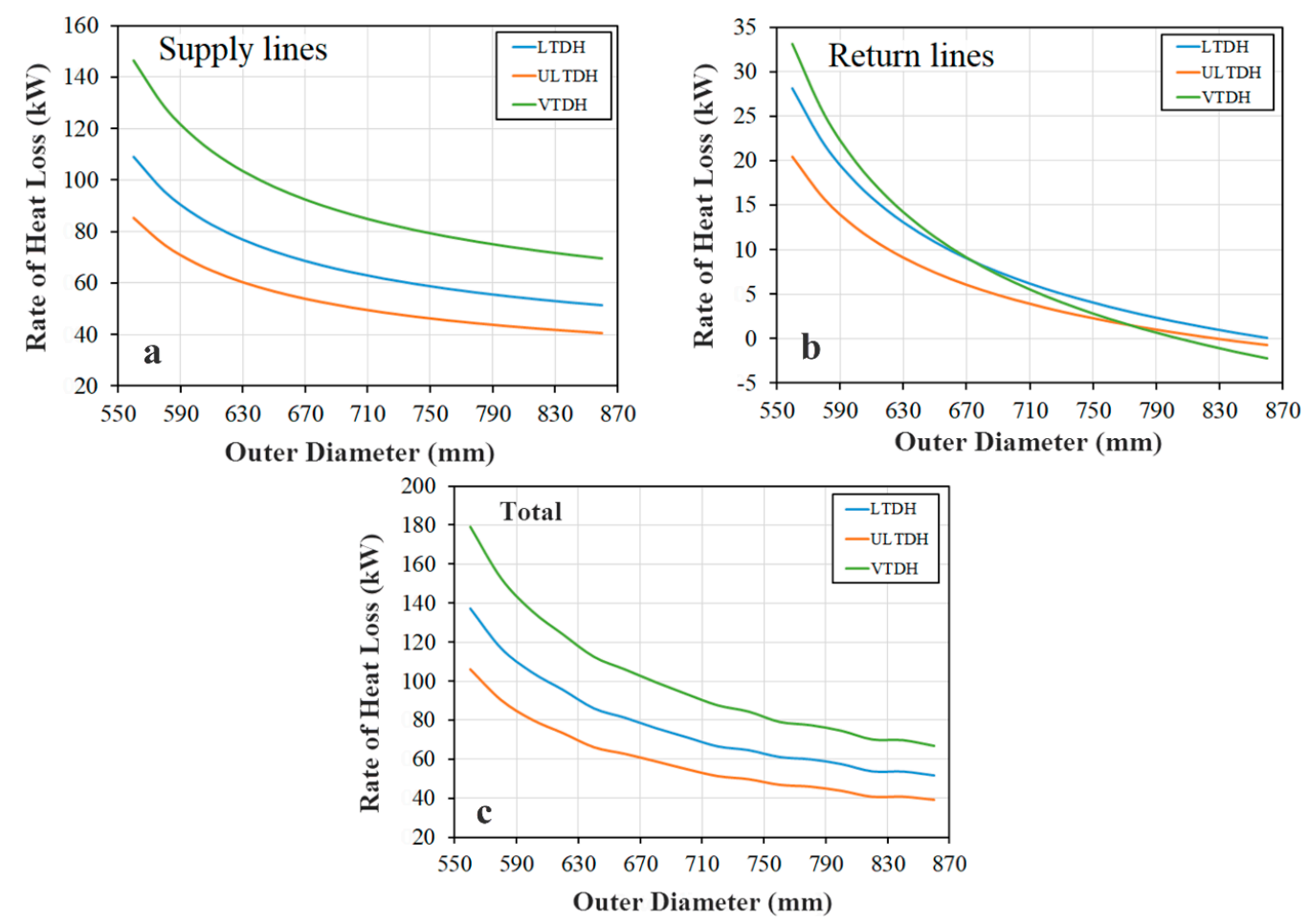

Figure 14. The effect of strengthening the insulation of pipes for various cases. (a) supply lines; (b) return lines; (c) total.

Figure 15 shows the variation of the outlet temperature of the supply and return lines of the VTDH system over time. The main objective is to investigate the effect of the thermal inertia of the pipe to see if this parameter allows the system to operate as the proposers [22] and investigators [23] of the system expect. For this, it is assumed that the system is in its ultralow-temperature supply mode $\left(45 / 25^{\circ} \mathrm{C}\right)$, and then suddenly, the high-temperature supply mode starts $\left(70 / 35^{\circ} \mathrm{C}\right)$. Naturally, as the operation mode changes, due to the long length of the pipe $(10 \mathrm{~km})$ and the limited velocity of the flow through the pipes ( $2 \mathrm{~m} / \mathrm{s}$ here), even if there is no external parameter affecting the flow, it would take time to reach the outlet point. In addition, it can be seen that even if the effects of the 
thermal inertia of the pipe is neglected, the external effects cause the outlet temperature to gradually approach the supply temperature. This will even take longer (almost double) when the effects of the thermal inertia of the pipe are taken into account. A similar trend is observed for the return line as well. Therefore, it is clearly seen that a VT supply could not be effectively taken for a pipeline as long as $10 \mathrm{~km}$, which is a very regular long of transmission pipeline in a district heating system.

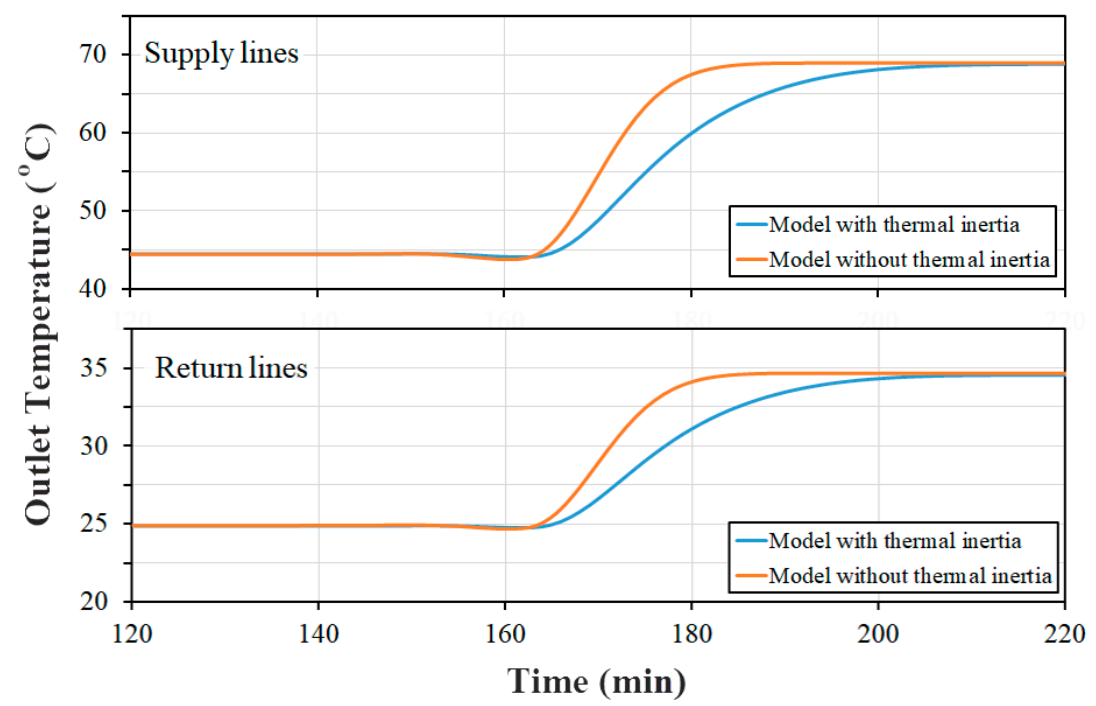

Figure 15. The effect of thermal inertia on the outlet temperature of the Variable-temperature district heating $(\mathrm{VTDH})$ system.

Figure 16 compares the trend of variation of the outlet temperature of a VTDH system when the length of the pipeline is $10 \mathrm{~km}$ and $1 \mathrm{~km}$. The former is as the previous case and the latter is based on what Arabkoohsar [24] proposed for the local use of decentralized heat pumps for increasing the temperature from $45^{\circ} \mathrm{C}$ to $70{ }^{\circ} \mathrm{C}$, which makes the length of pipe associated with the variation of the temperature below $1 \mathrm{~km}$. For this, a complete high-temperature, ultralow-temperature supply process, based on the given definition for this system, is accomplished. That is, the pipeline is first at $45^{\circ} \mathrm{C}$, then suddenly two hours of $70^{\circ} \mathrm{C}$ supply, followed by $2 \mathrm{~h}$ of $45^{\circ} \mathrm{C}$ supply, is applied.

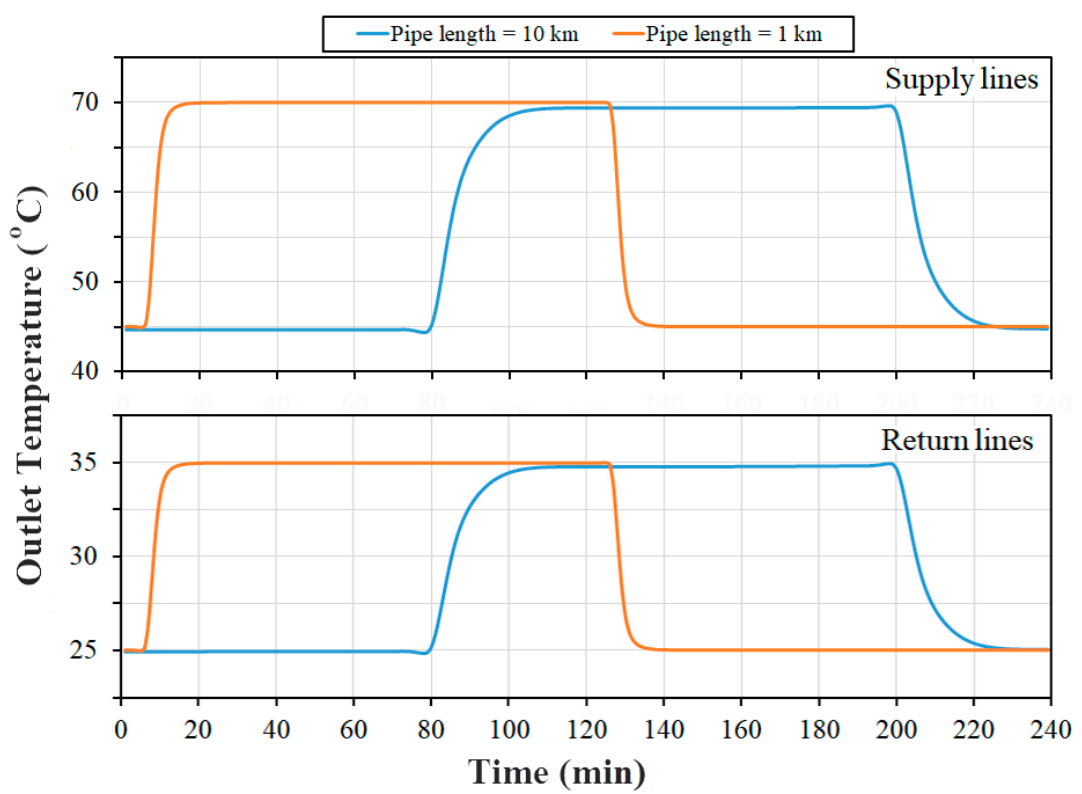

Figure 16. The trend of outlet temperature in a VTDH system with different pipe lengths. 
According to the figure, the outlet temperature of the long pipe gets quite disordered and kind of unexpected while the small length of the pipe for the second case makes the desired outlet temperature achievable after a short delay. This results in a favorable outlet temperature profile for the VTDH system with a short length of $1 \mathrm{~km}$ (e.g., a street branch pipe).

\section{Conclusions}

This study presents a thermal-hydraulic performance analysis of regular twin-pipes in the third generation district heating systems to investigate how they fit into the future district heating schemes. After presenting the general thermal and hydraulic performance assessment results of such pipes for all the three considered cases, i.e., the ULTDH, the LTDH and the VTDH systems, the effect of changing the insulation thickness and the thermal inertia of the pipe on the performance of each of the cases were investigated.

The results show that, expectedly, the ULTDH system shows the lowest rate of loss and temperature drop along the pipe, where the VTDH system results in a higher rate of loss and temperature drop when working on a high-temperature supply mode. The results show that the twin-pipe (as they are) may fit the ULTDH and LTDH systems while there seems to be space for strengthening the insulation of the pipes for a further reduction of the rate of losses in a cost-effective way. This, however, requires an economic trade-off to see how much would be gained for a certain amount of reinforcement of the insulation and how much this will increase the cost of the pipes.

On the other hand, it was shown that the concept VTDH system, as proposed in [22,23] would never be practically applicable. This is mainly because of the effect of the thermal inertia of the pipe. The other scheme of the VTDH system, i.e., the one proposed by Arabkoohsar [24], however, does not suffer from this problem as this concept brings the dynamic supply temperature to the pipes close to the end-users (below $1 \mathrm{~km}$ distance). Although the thermal inertia of the pipe affects the practically achievable supply temperature of the end-users in this system as well, the effect is so small that the system can reliably be employed by the regular existing twin-pipes.

Author Contributions: Simulations, validation of results and software tasks of this research work was carried out by M.K. A.A. contribution was supervision of the work, interpretation of the results and writing of the manuscript.

Funding: This research received no external funding.

Conflicts of Interest: The authors declare no conflict of interest.

\section{Nomenclature}

\section{Parameter Explanation}

$A_{o}, C, \sigma_{k}, \sigma_{\varepsilon}$ Turbulence model constant

$g_{i} \quad$ Gravity acceleration component

$h \quad$ Convective heat transfer coefficient/enthalpy

$k \quad$ Turbulent kinetic energy

$k_{\text {eff }} \quad$ Effective thermal diffusivity (heat transfer coefficient)

$k_{s} \quad$ Thermal conductivity of solid cell

LTDH Low-temperature district heating

Pr Prandtl number

$\mathrm{Pr}_{t} \quad$ Turbulent Prandtl number

$q \quad$ Rate of heat transfer/loss

$T_{f} \quad$ Local fluid temperature

$T_{w} \quad$ Local wall temperature

$u_{i}, u_{j}, u_{l} \quad$ Velocity components in the $i, j$ and $l$ direction

ULTDH Ultralow- temperature district heating

VTDH Variable-temperature district heating

$x_{i}, x_{j}, x_{l} \quad$ Cartesian coordinates in the $i, j$ and $l$ direction 


\section{Greek Symbols}

$\begin{array}{ll}v & \text { Kinematic viscosity } \\ \mu & \text { Dynamic viscosity } \\ v_{t} & \text { Turbulent viscosity } \\ \rho & \text { Density } \\ \delta_{i j} & \text { Kronecker delta function } \\ \varepsilon & \text { Dissipation of turbulence energy } \\ \beta & \text { Coefficient of thermal expansion } \\ \omega & \text { Angular velocity }\end{array}$

\section{References}

1. Dincer, I.; Acar, C. Smart energy systems for a sustainable future. Appl. Energy 2017, 194, 225-235. [CrossRef]

2. Mathiesen, B.V.; Lund, H.; Connolly, D.; Wenzel, H.; Østergaard, P.A.; Möller, B.; Nielsen, S.; Ridjan, I.; Karnøe, P.; Sperling, K.; et al. Smart Energy Systems for coherent 100\% renewable energy and transport solutions. Appl. Energy 2015, 145, 139-154. [CrossRef]

3. Lund, H.; Duic, N.; Østergaard, P.A.; Mathiesen, B.V. Smart energy systems and 4th generation district heating. Energy 2016, 110, 1-4. [CrossRef]

4. Werner, S. District heating and cooling in Sweden. Energy 2017, 126, 419-429. [CrossRef]

5. Werner, S. International review of district heating and cooling. Energy 2017, 137, 617-631. [CrossRef]

6. Mazhar, A.R.; Liu, S.; Shukla, A. A state of art review on the district heating systems. Renew. Sustain. Energy Rev. 2018, 96, 420-439. [CrossRef]

7. Ziemele, J.; Gravelsins, A.; Blumberga, A.; Vigants, G.; Blumberga, D. System dynamics model analysis of pathway to 4th generation district heating in Latvia. Energy 2016, 110, 85-94. [CrossRef]

8. Nord, N.; Nielsen, E.K.L.; Kauko, H.; Tereshchenko, T. Challenges and potentials for low-temperature district heating implementation in Norway. Energy 2018, 151, 889-902. [CrossRef]

9. Gadd, H.; Werner, S. Achieving low return temperatures from district heating substations. Appl. Energy 2014, 136, 59-67. [CrossRef]

10. Im, Y.-H.; Liu, J. Feasibility study on the low temperature district heating and cooling system with bi-lateral heat trades model. Energy 2018, 153, 988-999. [CrossRef]

11. Cai, H.; You, S.; Wang, J.; Bindner, H.W.; Klyapovskiy, S. Technical assessment of electric heat boosters in low-temperature district heating based on combined heat and power analysis. Energy 2018, 150, 938-949. [CrossRef]

12. Averfalk, H.; Werner, S. Novel low temperature heat distribution technology. Energy 2018, 145, 526-539. [CrossRef]

13. Li, Y.; Xia, J.; Su, Y.; Jiang, Y. Systematic optimization for the utilization of low-temperature industrial excess heat for district heating. Energy 2018, 144, 984-991. [CrossRef]

14. Yang, X.; Svendsen, S. Achieving low return temperature for domestic hot water preparation by ultra-low-temperature district heating. Energy Procedia 2017, 116, 426-437. [CrossRef]

15. Yang, X.; Svendsen, S. Ultra-low temperature district heating system with central heat pump and local boosters for low-heat-density area: Analyses on a real case in Denmark. Energy 2018, 159, 243-251. [CrossRef]

16. Vivian, J.; Emmi, G.; Zarrella, A.; Jobard, X.; Pietruschka, D.; de Carli, M. Evaluating the cost of heat for end users in ultra low temperature district heating networks with booster heat pumps. Energy 2018, 153, 788-800. [CrossRef]

17. Zühlsdorf, B.; Meesenburg, W.; Ommen, T.S.; Thorsen, J.E.; Markussen, W.B.; Elmegaard, B. Improving the performance of booster heat pumps using zeotropic mixtures. Energy 2018, 154, 390-402. [CrossRef]

18. Ommen, T.; Thorsen, J.E.; Markussen, W.B.; Elmegaard, B. Performance of ultra low temperature district heating systems with utility plant and booster heat pumps. Energy 2017, 137, 544-555. [CrossRef]

19. Thorsen, J.E.; Ommen, T. Field experience with ULTDH substation for multifamily building. Energy Procedia 2018, 149, 197-205. [CrossRef]

20. Knudsen, M.D.; Petersen, S. Model predictive control for demand response of domestic hot water preparation in ultra-low temperature district heating systems. Energy Build. 2017, 146, 55-64. [CrossRef]

21. Johnson, R.C. Variable Temperature Water District Heating; ResearchGate: Berlin, Germany, 1986. 
22. Rindt, C. Optimization of a Variable Temperature 4th Generation District Heating Network Using the CONICO Thermo-Differential Valve Technology. Available online: https:/ /www.researchgate.net/project/ Optimization-of-a-variable-temperature-4th-generation-district-heating-network-using-the-CONICOthermo-differential-valve-technology (accessed on 1 April 2019).

23. Moallemi, A.; Arabkoohsar, A.; Pujatti, F.J.P.; Valle, R.M.; Ismail, K.A.R. Non-uniform temperature district heating system with decentralized heat storage units, a reliable solution for heat supply. Energy 2018, 167, 80-91. [CrossRef]

24. Arabkoohsar, A. Non-uniform temperature district heating system with decentralized heat pumps and standalone storage tanks. Energy 2019, 170, 931-941. [CrossRef]

25. Lund, H.; Werner, S.; Wiltshire, R.; Svendsen, S.; Thorsen, J.E.; Hvelplund, F.; Mathiesen, B.V. 4th Generation District Heating (4GDH): Integrating smart thermal grids into future sustainable energy systems. Energy 2014, 68, 1-11. [CrossRef]

26. Logstor, D.H. Pipeline Developer. Available online: https://www.logstor.com/ (accessed on 3 April 2019).

27. White, F.M. Fluid Mechanics; Mc Graw Hill Book Company: New York, NY, USA, 1986.

28. Tennekes, H.; Lumley, J.L. A First Course in Turbulence, 6th ed.; MIT Press: Cambridge, MA, USA, 1972.

(C) 2019 by the authors. Licensee MDPI, Basel, Switzerland. This article is an open access article distributed under the terms and conditions of the Creative Commons Attribution (CC BY) license (http:/ / creativecommons.org/licenses/by/4.0/). 